\title{
Adoption of Russian children by foreign citizens: some problems concerning the implementation of norms of international law
}

\author{
Eugene S. Anichkin ${ }^{1}$, Kseniya E. Kovalenko ${ }^{2}$ and Anton A. Vasiliev ${ }^{3}$ \\ 1 Doctor of Legal Sciences, associate professor, Altai State University, Barnaul, Russian Federation. \\ E-mail: rrd231@ramblerl.ru \\ 2 Candidate of Legal Sciences, associate professor, Altai State University, Barnaul, Russian Federation. \\ E-mail: kovalenko1288@mail.ru \\ 3 Doctor of Legal Sciences, associate professor, Altai State University, Barnaul, Russian Federation. \\ E-mail: anton vasiliev@mail.ru
}

\begin{abstract}
The issues of intercountry adoption are a matter of discussion for all world community in view of the fact that it is practically impossible to ensure proper regulation of all aspects of the adoption procedure and, moreover, it is possible to encounter various conflicting rules for the regulation of the adoption procedure between the State of child origin and the receiving State. The article outlines the prospects for ratifying the Hague Convention on Protection of Children and Cooperation in the Field of Intercountry Adoption of 29 May 1993 and the European Convention on the Adoption of Children (revised) of 27 November 2008. Adoption procedure should be in the best interest of the child in relation to his fundamental rights. The tension in the sphere of adoption of children left without parental care by US citizens is given proper consideration. Compliance with international norms and rules is reflected in the "Dima Yakovlev Law" which is difficult to recognize as effective in its capacity to ensure the rights and interests of children. It was revealed that the implementation of the abovementioned international acts in the Russian legal space will bring positive results due to a significant simplification of the procedure for reviewing and resolving cases on the adoption establishment.
\end{abstract}

Keywords: Intercountry adoption. International acts. Implementation. Conflict-of-laws rules. Barriers to unification.

\section{INTRODUCTION}

According to the statistics of the Ministry of Education and Science of the Russian Federation, adoption is currently the least popular form of placement of children deprived of parental care. In 2015 a decrease in the number of adoptions, both intercountry and domestic, was recorded which reveals a number of serious problems both in legal regulation and in the mechanism for implementing the norms of law in practice.

However, the problem of adoption of children has recently become particularly urgent which is due to a complex of political, social and legal factors. In international law, as well as in the Family Code of the Russian Federation, the inalienable right of children to live and be brought up in the family is enshrined.

The State is obliged to provide social protection for a child deprived of a family environment, offering an alternative opportunity in the choice of family education. The provisions proclaimed by the UN Convention on the Rights of the Child set the priori- 
ty of family forms for the placement of children deprived of parental care, compared with the practice of placing them to specialized institutions (orphanages), which primarily meets the interests of the child and society. Among the forms of family education of children, legislation gives priority to adoption since the institution of adoption is the realization of the child's right to live and be brought up in the family.

The given issue was researched both by Russian scientists: Alieva Z. Z., Antokolskaya M. V., Baturina N. I., Buyanova E. V., Vershinina G. I., Dzugaeva A. Z., Nechaeva A. $M$. and others, and foreign scholars: Barbara Melosh, Joanna L. Grossman, David M. Brodzinski, Karen Dubinskiy, Katherine SenizahChoi, Linda J. Seligmann, Fiona Bowie, Timothy P. Jackson, Lawrence M. Friedman and others.

The tension in the sphere of adoption of children deprived of parental care by foreign citizens should be given proper consideration. Compliance with international norms and rules is reflected in the "Dima Yakovlev Law" which provides for the prohibition of adoption of children - citizens of Russia by US citizens. Time will tell if this law will eliminate the problem but this document can not be considered effective in its capacity to ensure the rights and interests of children.

The dialectical method was applied to examine the dynamics of intercountry adoption of Russian children by foreigners. The method of interpretation identified the problems of applying the conflict-of-laws rules of the Family Code of the Russian Federation and foreign law and, furthermore, the jurisprudence of the European Court of Human Rights in the field of intercountry adoption is analyzed. The establishment of the content of norms of foreign law leads to the prolongation of the process even at the stage of preparing the case for trial, when the court refers inquiries to the relevant services, calls experts in the field of foreign law.

The mandatory limitation of the period of consideration of the case, stipulated by Item 1 of Article 154 of the Russian Federation Code of Civil Procedure, is not an effective guarantee of timely consideration of the case. The implementation of the Hague Convention on the Protection of Children and Cooperation in the Field of Intercountry Adoption of 29 May 1993 and the European Convention on the Adoption of Children of 27 November 2008 into the Russian legal space would significantly simplify the consideration and resolution of cases on the establishment of adoption procedure, thus, reducing the period of case consideration.

\section{DEVELOPMENT}

A harmonious community functions properly when its members are selfsufficient citizens who respect themselves and the State. This is largely due to the education of these citizens to respect the law, to love the motherland and the family which creates ideal microenvironment to nurture and educate a reliable member of society. These postulates are adopted by the international and national legislation of many countries which gives adoption a priority over the other forms of the placement of children. The Convention on the Rights of the Child approved by the UN General Assembly on 20 November 1989, stipulates that the child, due to his physical and mental immaturity, needs special protection and care, including proper legal protection, both 
before and after birth.

The Convention underlines the fact that a child can receive full care and protection only in a family environment, in an atmosphere of happiness, love and understanding.

Unfortunately, for one reason or another (death, deprivation of paternal rights), children are left without parental care. Despite the annual reduction in the number of orphans in our country, their number is extremely high. Thus, according to the statistics of the Ministry of Education and Science of the Russian Federation at the end of 2015, the number of orphans in Russia accounted for 482 thousand people. The State takes care of these children in order to create conditions for growth and development and provide them with conditions for a decent human existence. However, adoption is given priority when placement is arranged for children without parental care (Item 1 of Art. 124 of the Family Code of the Russian Federation). According to statistics for 2015 , out of 482,000 orphans 6649 children were adopted $(1.4 \%$ of the total number of orphans), of which 663 children were adopted by foreign citizens. Whereas, 3,070 children $(6.2 \%$ of the total number of orphaned children) were placed for guardianship and trusteeship, and 20,707 (4.3\%) were transferred to adoptive families. The following data vividly illustrates that despite the provisions on the priority of adoption contained in the basic normative acts, Russian citizens prefer to register custody (guardianship) over the child or enter into a adoptive family contract.

This is quite understandable. For example, in Altai Region, a citizen who adopted a child receives a lump sum payment in the amount of RUB 17 839.56.

If an adopted child is with disabilities and older than 7 years or siblings are adopted, a lump sum is paid in the amount of RUB 136 308.64 for each child. When the child is taken into custody (guardianship), 10 174.05 rubles are paid monthly to the adoptive family for the maintenance of one child. Adoptive parents are also remunerated for raising a child in the amount of 4 115.16 rubles. It is not difficult to compare the amount of material assistance provided by the state to adoptive parents on the one hand and guardians (trustees) on the other in order to conclude that guardianship will be given preference in a current tough economic situation in our country.

One can understand the differentiated approach of the legislation to determining the amount of material support for this category of persons. The granting of an adoption order transfers all legal responsibility and rights to the adoptive parents, according to which the adopted children and their offspring in relation to the adoptive parents and their relatives, and the adoptive parents and their relatives in relation to the adopted children and their offspring are equated in personal non-property and property rights and duties to relatives of origin. It is no accident, in pre-revolutionary Russia, adoption was called "artificial sonship".

Others define adoption as an individual permanent (lifelong) form of the placement of children left without parental care, when special legal relationship between the adopter and the adopted child is established, resembling the relationship between the parent and the child. Adoption order, as indicated in the legal literature, shall grant a permanent placement of the child, the 
rights and duties of adopted children and adoptive parents may amount to the rights and duties of children and parents. It can be said that adoption has a similarity to first degree kinship. Despite the different approaches to the definition of the concept of "adoption", it is common for all researchers of Russian family law to recognize the consequences of adoption. Consequently, a citizen who adopted a child becomes a parent not only and not so much in a legal sense as in ethical and moral, emotional sense, thus, willing to assume the responsibility to replace a parent to an orphaned child. It seems such a citizen should be concerned about the amount of state aid to a lesser degree. Other motifs would allow us to talk about the hidden, illegal form of receiving money.

Guardianship (trusteeship) as a form of placement of children in the family is given less priority than adoption and is considered a temporary form of the placement of a child left without parental care, which assumes only individual assistance and care by a certain individual (persons).

Being an individual form of the placement, guardianship (trusteeship) is intended, first of all, to compensate for the missing capacity of the child in ward, as well as for his upbringing. The guardianship is terminated when the child attains the age of 14 years, and the citizen who has performed the duties of the guardian automatically, without additional decision becomes a trustee. Trusteeship, in turn, terminates with the acquisition of full civil capacity by the child.

An adoptive family is a type of guardianship (trusteeship) over a child (children), which is carried out under a adoptive family contract concluded between the guardian- ship authority and adoptive parents (adoptive parent), within the period specified in the contract (Item 1 Art. 152 of the Family Code of the RF). Adoptive parents, as mentioned earlier, are rewarded for upbringing a child. This contract shall cease to be effective upon termination of guardianship and trusteeship (Art. 153.2 of the Family Code of the RF). Not setting the goal to identify the general and special in the given forms of the placement of children, it is to be noted that international and domestic legislation apply a reasonable and balanced approach to setting priorities for the placement of children, left without a family for any reason.

In view of the foregoing reasons, it is not quite clear why the Russian state remains so passive in providing assistance to concerned citizens, including foreigners, in the adoption of children. In our opinion, it is necessary not only to popularize such a form of placing children in the family as adoption, but also to improve legislation in this area.

For the reason of concern about the fate of orphaned children which is no less than in any particular state, International community has adopted two significant documents containing only unified substantive rules: the Hague Convention on Protection of Children and Cooperation in the Field of Intercountry Adoption of 29 May 1993 and the European Convention on the Adoption of Children (revised) of 27 November 2008. It should be noted that there are 96 states signatory to the Hague Convention as of 21 September 2016 and 49 states that are signatory to the European Convention as of 23 March 2017. Both conventions have not been ratified by the Russian Federation. The Hague Convention of 1993 and the Europe- 
an Convention of 2008 are complementary as indicated in the preamble of the latter.

Both conventions are based on the principles defined in the United Nations Convention on the Rights of the Child (Russia has been a party to it since 13 June 1990) and shall be applied where a child habitually resident in one Contracting State ("the State of origin") has been, is being or is to be moved to another Contracting State (the "receiving State") either after his or her adoption in the State of origin by spouses or a person habitually resident in the receiving State, or for the purposes of such an adoption in the receiving State or in the State of origin (Art. 2 of the Hague Convention).

The preamble to the Hague Convention also states that family education and the residence of a child in the country of origin are recognized as a priority for the child. Foreign adoption is possible when it is effected in the best interests of the child and with respect for his fundamental rights, and only when it can provide the child with the benefits of having a permanent family unless a suitable adoptive family cannot be found for him in the country of origin. The objectives of the Convention are:

- to establish safeguards to ensure that intercountry adoptions take place in the best interests of the child and with respect for his or her fundamental rights as recognized in international law;

- to establish a system of cooperation amongst Contracting States to ensure that those safeguards are respected and thereby prevent the abduction, the sale of, or traffic in children;

- to secure the recognition in Contracting States of adoptions made in accordance with the Convention.

The Convention regulates in detail the conditions and procedure for the adoption of children of one state by citizens of another Convention state. The State of origin of the child must establish that the child is adoptable and determine, after possibilities for placement of the child within the State of origin have been given due consideration, that an intercountry adoption is in the child's best interests; it shall ensure that persons, institutions and authorities, whose consent is necessary for adoption, have been counselled as may be necessary and duly informed of the effects of their consent, in particular whether the adoption will result in the termination of the legal relationship between the child and his family of origin (persons, institutions and authorities have given their consent freely, in the required legal form, expressed or witnessed in writing, consent have not been induced by payment or compensation of any kind and has not been withdrawn and the consent of the mother, where required, has been given only after the birth of the child); it shall also ensure, having regard to the age and degree of maturity of the child, that he or she have been counselled and duly informed of the effects of the adoption and of his or her consent to adoption, where such consent is required; it must observe whether the child's views and preferences have been given consideration; whether the child's consent to adoption [if such consent is required] has been received freely, in proper legal form, expressed or witnessed in writing, and such consent has not been induced by payment or compensation of any kind.

In turn, the competent authorities of the receiving State shall, firstly, determine that the prospective adoptive parents are eligible and suited to adopt; second, ensure 
that prospective adoptive parents have been fully counselled as may be necessary; third, determine that the child is or will be authorized to enter and reside permanently in that State.

The States that have joined the Convention recognize the adoption of the State where the adoption process was completed. The official acceptance of the adoption means recognition of the legal relationship between the child and his/her adoptive parents, the adoptive parents' responsibility for the child, and the termination of the pre-existing legal parent-child relationship. These conditions are dependent upon whether or not the adoption procedure has similar effects in the Contracting State where the adoption process is completed.

The Hague Convention contains general provisions on the possibility of adoption (Art. 4a), the child's consent to the adoption (Art. 4d), and the readiness of prospective parents to adopt a child into the family (Art. 4c), all regulated by the procedural relationship between the receiving and sending States (Chapter IV).

The European Convention, by contrast, contains specific and detailed provisions on the child's consent to the adoption (Art. 5) as well as consideration of the child's opinions and interests (Art. 6). Moreover, the Convention determines the conditions for adopting a child (Art. 7), the age of the adoptive parents (Art. 9) and regulates the activities of the relevant competent authorities (Art. 10).

It should be pointed out that the ratification of the European Convention does not abolish the judicial procedure of adoption establishment and does not supersede the applicable national law(s) of the State in question.
The norms of the European Convention do not contain provisions that violate the spirit and purposes of the Constitution of the Russian Federation and the Family Code of the Russian Federation, except Item 2 of Article 7, which allows the adoption of a child (children) by same-sex couples living together. However, it is not worthwhile to reject the ratification of the Convention only for this reason.

According to the official statistic presented in the 2015 Review of Court Practices regarding regional court cases on adoption by foreign citizens or stateless persons, as well as citizens the Russian Federation permanently residing outside of the Russian Federation, most Russian children are adopted by Italian citizens ( $57 \%$ of cases), Spanish citizens $(17.5 \%$ of cases), and French citizens (5.9\% of cases).

It is generally well-known that same-sex marriage is legally recognized in Spain. In fact, at the time of adoption, the adopter can legally be unmarried, married to a person of the same sex, or married to a person of the opposite sex. There is no a guarantee that an individual won't divorce and create a same-sex family or that the child won't join a family representing a symbiosis of different-sex or same-sex couples. The above-mentioned fact cannot prevent Russian courts from granting the adoption of requests applied by Spanish citizens. Therefore, our legislation cannot ensure that a Russian child will not reside in a same-sex family in the receiving state. At the same time, Item 1 of Article 27 of the European Convention allows accession to the Convention with a reservation as to the provisions of Article 7. Thus, the Russian Federation could, by means of such a reservation, establish an effective mechanism for protect- 
ing the rights and interests of Russian children.

The lack of these conventions in the Russian legal space results in a number of difficulties both substantive and procedural. It is generally accepted that the legal regulation of family relations in different countries is extremely varied and is often determined by differing historical, cultural, and ethnic considerations.

According to some studies, the system of cross-border adoption has a number of pitfalls which are differences in legislation and culture. Many scientists claim that cultural differences shall be respected and preserved, while other researchers argue that they put barriers to the unification of international norms in this field. For example, it is stated that the impossibility of adopting orphans from the Middle East by Europeans can be attributed to respect for the culture of these countries where adoption contradicts religious norms. Meanwhile, it is necessary to understand whether the unification of legislation in the field of intercountry adoption is so unpromising and harmful. The opponents believe that under the current conditions of intensive intercountry exchanges, marriage and family law, as no other set of relations and rules regulating them, are subject to the norms of international communication and the impossibility of regulating them through the law and order of one State only. We believe that it is quite relevant at present to consider the possibility of applying international unified norms for regulating intercounry adoption, thus, gradually stepping away from the application of the several norms of law and order.

Taking into account the legal effects of adoption, it is necessary to understand that a child - a citizen of one State, adopted by citizens of another State for the purpose of forming a full family, is unlikely to maintain strong ties with the State of origin. It is logical to assume that he or she will study the language of the country of adoptive parents, attend school there, continue studying, work, make his/her family, i.e. participate in the life of society and the country, being involved into the cultural, linguistic and family traditions of another State. Children with serious diseases, such as cerebral palsy, Down syndrome (adopted by foreign citizens mostly) are unlikely to understand the depth and value of the traditions of their State of origin. Therefore, the application of several norms of law and order in the establishment of adoption does not guarantee the preservation of cultural, clan ties with the State of origin and protection of the rights of the adopted person. It is much more important to provide such a child with effective safeguards of protection of his rights in another State in case of violation and it can be effected through international conventions and bilateral treaties and agreements.

Adoption is to be given priority when the placement is arranged for orphans and other children currently without parental care. Consequently, the inaction of States, namely the Russian Federation, in implementing international norms in the Russian legal space violates children's rights to live and be brought up in a family. It is necessary in Russia to strengthen legislative regulation in the field of intercountry adoption. The previously established international acts in this field should continue to be within the basic framework.

Conflict-of-laws rules for intercountry adoption and their irresolvable problems 
attract the attention of scholars, give rise to discussions that are annually analyzed by the legal press. However, academics are not aware of some difficulties that courts face dealing with such issues. It should be noted that legislation of different States in the consideration of the case on adoption establishment, can apply personal law of the adoptive parents (German Law), adoptee (French Law), their cumulative application (Russian Law).

\section{RESULT.}

In fact, the content of the adoption statute is quite topical. In some countries, the statute of the adoption contains less rights than the statute of inheritance (England). One of the most urgent problems in today's society is recognition of intercounty adoption. So, in some states of the USA (lowa, Rhode Island, Virginia), a special visa is issued to the adoptee. The adoption procedure is complete only after consideration of adoption in the court of the appropriate state. Accordingly, there is a process of "readoption" of the child. In Switzerland, the adoption procedure is identical. In the United Kingdom of Great Britain, foreign adoptive parents cannot be recognized if the British court does not have jurisdiction to issue an order on adoption.

In adoption cases by foreign nationals, conflict-of-law issues can occur and become further complicated by the "foreign element". Regulation of conflict -of-law issues regarding adoption cases is carried out at the international, regional and national level. At the regional level, conflict regulation and resolution of adoption cases are governed by the Minsk and Kishinev Conventions, "On Legal Assistance and Legal Rela- tions in Civil, Family, Criminal Cases" adopted in 1993 and 2002. According to these international treaties, the adoption procedure or its abolition is carried out according to the legislation of the State in which the child is a citizen, unless otherwise stated.

Adopting a child who is a citizen of one of the Member States of the CIS Conventions or abolishing an adoption process requires the consent of the legally authorized representative and the competent state body, as well as the child's consent if such a statement exists in the personal law of the adoptee.

When the child is adopted by spouses who are citizens of different State parties of the $\mathrm{CIS}$, the adoption procedure or its abolition is carried out under the legislation of both countries. The state, in which the adopter is a citizen at the time of the application for adoption or its abolition, is responsible for the adoption procedure or its abolition. In the case of different spouses' nationality, a competent authority is considered the authority of the State, in which the spouses have or last had a common place of residence.

Unfortunately, the norms of the Convention do not specify what a competent state body or institution can give in terms of 'consent' to a foreign citizen. It would be logical to assume that the competent state body in which a child is a citizen can give its consent to a foreign citizen. The consent of the consular authorities or diplomatic mission in the adoption procedure of a foreign citizen would be appropriate and would provide a child (children) with legal assistance.

As for the national legislation of the CIS countries, it should be noted that not all foreigners are allowed to adopt children 
deprived of parental care. For example, Family Law of the Republic of Tajikistan does not participate in inter-country adoption. In accordance with Article 127 of the Family Code of RT, the adoptive parents can only be adult citizens of the Republic of Tajikistan, except for adopters who do not have a well-defined place of residence; have previous convictions for a premeditated offence at the time of adoption; persons who have been prescribed compulsory medical treatment for committing a crime by court orders; persons declared by court legally incapable or of limited legal capacity; if one of the spouses recognized by a court as legally incompetent or of limited competence; persons deprived of their parental rights or restricted in parental rights by a court order; persons discharged from obligations of a guardian/trustee owing to improper performance of his/her duties imposed on them by law; former adoptive parents, if the adoption is revoked or declared invalid by the court by their fault; or persons who, due to their state of health, cannot exercise their parental rights. Despite the national legislation of Tajikistan, in judicial practice there are cases of children's adoption by foreign citizens, which are based on the interests of children's views and preferences, for example, the case of the adoption of minors (the Shodievs) by a citizen of Germany (Eberly A.).

In our opinion, the ban on intercountry adoption established by the national legislation of the Republic of Tajikistan does not contradict the provisions of the Kishinev Convention, since conflict-of-laws rules on the adoption establishment of this international treaty contain references to the personal law of the adoptee - a citizen of the Republic of Tajikistan. In its turn, personal law does not allow a child's adoption by foreigners and stateless persons.

The National Law of the USA in respect of intercountry adoption focuses mainly on the child's interests and preferences. When adopted abroad, the applicable law is personal law of the adopter or the child's personal law but not the law of the court. The personal law of the adoptive parents regulates the preconditions for the adoption procedure, and the child's personal law is applicable in cases when it is necessary to obtain consent for the adoption procedure in the child's country of origin. To recognize an intercountry adoption in the United States, essential conditions are to issue relevant documents by an appropriate court, and to apply an appropriate law. Intercountry adoption should correspond to the personal rights of the adopter as well as the child.

The national legislation of the Federal Republic of Germany also indicates rights and interests of children as an significant principle in intercountry adoption. The conflict-of- laws rules relating to adoption in the Federal Republic of Germany are subordinated to the legislation of the state in which the adoptive parent is a citizen (Art. 22 of the Introductory Law to the German Civil Code). Legislation prohibits the adoption of children by persons who are stateless. In turn, Austrian legislation declares that intercountry adoption is a complex and comprehensive procedure. Moreover, it (Austrian legislation) raises the question of legitimacy of the procedure itself. Illegal adoptions can result in recognizing its legitimacy, in particular, it is necessary to resolve a problem with a child's legal residence in the territory of Austria and transfer a child to the child's country of origin. 
Scholars specializing in intercountry adoption state that the child's best interests should be considered in the adoption process, namely, services, actions, and orders that will best serve a child as well as who is best suited to take care of a child. For instance, V.P. Zvekovoy pointed out that an adoption may not take place if it may result in an infringement of the child's right under legislation and international agreements, regardless of the citizenship of the adopter. If the adoption procedure does not meet a child's best interest, it is subject to cancellation.

Currently, the court dealing with the adoption procedures of a Russian child by foreign nationals applies international treaties of the Russian Federation (Item 1 (3) Art. 165 of the Family Code of the RF), the law of the adopter's country (Item 1 Art. 165 of the Family Code of the RF) and also monitors whether the requirements of a number of articles of the Family Code of the RF are applied (Item 1 (2) Art. 165 of the Family Code of the RF). Having initiated the case, the court must establish the content of the legislation of the state in which an adoptive parent is a citizen (Item1 Art. 166 of the Family Code of the RF). According to a legal literature survey, the conflict-oflaws rules (Item 1(1) Art.165 of the Family Code of the RF) raise complex practical problems in establishing the content of foreign law. Foreign law (Item1 Art. 116 of the Family Code of the RF) should be applied by the Russian court in accordance with its official interpretation, practice of application and doctrine in the relevant State. Consequently, foreign law should be applied as it is interpreted and applied in the relevant State. In this regard, the Russian court may request legal assistance from the Ministry of Justice of the Russian Federation, other competent authorities, or to use a group of experts (Item 1 (2) Art. 166 of the Family Code of the RF). It is quite possible that the Russian court will not be able to establish the content of the legislation of foreign law. In this case, the court must reach a decision by applying Russian legislation (Item 3, Article 166 of the Family Code of the R F).

According to the survey, $100 \%$ of judges do not refer to Article 165 of Family Code of the Russian Federation when they decide on the international adoption establishment. Among the reasons for ignoring a conflict of laws, the majority of judges (70\%) outline that there is a lack of mechanisms for providing information on Foreign Law. The Ministry of Justice of the Russian Federation is failing to cope with requests and simply notes it is impossible to obtain information on the legislation of the requested State.

The legal consequences of nonapplication of the regulations of foreign law may threaten both the protection of the child's interests and the adoption procedure itself. Also, it can occur that the legislation of the country, in which the adopter is a citizen, does not allow the adoption procedure or the foreign legislation establishes a high age requirement for perspective adopters that significantly differs from the provisions of the Family Code of the RF, the Civil Code of the Russian Federation . The establishment of the norms of foreign law results in further delays while the court hearing is still at the preparatory case, and when the court sends requests to the relevant state bodies and looks for experts in the foreign law.

Mandatory legislation limiting of time needed to deal with these cases (Item 1 
Article 154 of the Russia Federation Code of Civil Procedure) cannot guarantee timely trials of the cases. The policy of the State in the respect of intercountry adoption, in our opinion, should be extremely balanced and well-considered. In the era of politicization of all aspects of human activities (art, religion, etc.), one should have both wisdom and awareness to understand the nature of essential affairs and should not transfer legal regulations of such relations into the political domain. In particular, the Dima Yakovlev Law bans U.S. citizens from adopting children who are Russian citizens and suspends the activity of organizations which select and place children (Russian citizens) in families of U.S. citizens (Art. 4). It is reasonable to assume that one should refrain from banning in order to safeguard and protect children's best interests. In fact, this law deprives children of an opportunity to be adopted and have a family. The mentioned law resulted in the unprecedented order issued by European Court of Human Rights on the complaint of 45 American citizens. The U.S. citizens were not able to complete the adoption procedure of Russian orphans. Despite the harsh statements published in the media that American parents were concerned only with protecting their rights and assessing compensation for moral damage, it would be fair to refer to the court decision. For example, Dmitry Dedov, an authorized Russian judge of the $E C H R$, agreed with most of the provisions of the court decision, pointing out that the nature of the dispute is quite specific. Undoubtedly, the applicants were eager to create families passing through the adoption procedure as required by national legislation but the authorities blocked their attempts. Also, the opinion of the third par- ty involved in the process, the representatives of the Harvard Law School's Child Advocacy Program, is extremely significant. They refer to scientific studies on national and intercountry adoption procedures which stress the necessity of having a family at an early age. It is known that if children posses a family at an early age it is very essential for their physical, emotional, and cognitive development. Studies have shown that adoption at the earliest age is the key to creating good relations within the family (Item $\mathbf{4 4 0}$ of the ECHR decision).

It is necessary to agree with stated views. Moreover, taking into account the provisions of Item 4 of Article 124 of the Family Code of the Russian Federation on the adoption of Russian children by foreign nationals (only if it is impossible to place the children with Russian families permanently domiciled in the Russian Federation or to have them adopted by the children's relatives regardless of their citizenship and place of residence), it can be assumed that the children were deprived the chance of possessing a new family.

\section{CONCLUSION}

Joining the Hague Convention on Protection of Children and Cooperation in the field of intercountry adoption of 29 May 1993 and the European Convention on the Adoption of Children (revised) of 27 November 2008 would be a significant step towards civilized intercountry adoption, since these international agreements contain mechanisms for preventing violation in the adoption procedure. In addition, this form of arrangement is used only in the interests of the child, if there is a lack of opportunity to provide a child with a family environment in 
the country of his/her origin. The implementation of these international instruments in the Russian legal space would greatly simplify the consideration and resolution of cases involving the adoption procedure and would assist in reducing the wait times for hearing cases.

\section{REFERENCES}

DOUGLAS A., PHILPOT T. Adoption: changing families, changing times, Routledge, 2003. https://doi.org/10.4324/9780203167434 Review of the practice of considering in 2015 by regional and equal courts cases on the adoption of children by foreign citizens or stateless persons, as well as by citizens of the Russian Federation permanently residing outside the territory of the Russian Federation. Ut. Presidium of the Supreme Court of the Russian Federation 27.04.2016. Bulletin of the RF Armed Forces, 9, 2016.

NECHAEV A.M. Family law: Textbook, 2011. VLADIMIRSKY-BUDANOV M. Review of the history of Russian law, Issue 2, 1886.

KRASHENINNIKOV P.V. Family law: Textbook, 2016.

TiMOTHY P. J. The Morality of adoption: social-psychological, theological, and legal perspectives, 2005.

Brodzinsky D. M. Psychological issues in adoption: research and practice. Praeger, 2005.

DUBINSKY K. Babies without borders: adoption and migration across the Americas. New York University Press, 2010. https:// doi.org/10.3138/9781442686120

TRINCHENKO K.O. Cross-border adoption: problems of recognition. Modern law, 2015, 6.

ANUFRIEVA L.P. Private International Law. The special part. Moscow. 2000.

DMiTRIEVA G.K. Private International Law.

Textbook for bachelors. Moscow. 2015.
TRINCHENKO K.O. Cross-border adoption: problems of recognition. Modern law, 2015, 6.

STREGO V.E. Adoption of children with participation of foreign citizens. Civilian. 2009, 4.

FEDOSEEVA G.Yu. A glance at the problem of international adoption from the point of view of private international law. Lex Russica, 2006, N 2.

MATVEEVA N.V. Adoption of Russian children by foreigners: the system and stages. Laws of Russia: experience, analysis, practice, 2008, 1.

SELIGMANN L. J. Broken links, enduring ties: American adoption across race, class, and nation. Stanford University Press, 2013. CHOY C. C. Global Families: A History of Asian International Adoption in America. New York University Press, 2013. https:// doi.org/10.18574/nyu/9780814717226.001. $\underline{0001}$

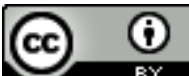
access article distributed under the terms of the Creative Commons Attribution License, which permits unrestricted use, distribution, and reproduction in any medium, provided the original work is properly cited.

Article received on April 11, 2019.

Evaluated July 26,2019.

Accepted on August 05, 2019.

Published on August 07, 2019.

How cite this article (ABNT):

ANICHKIN, Eugene S.; KOVALENKO, Kseniya E.; VASILIEV, Anton A. Adoption of Russian children by foreign citizens: some problems concerning the implementation of norms of International Law. Estação Científica (UNIFAP), Macapá, v. 8, n. 3, p. 25-36, Sept./ Dec. 2018. 